\title{
EXPLORING MY ROLE MODELLING AS A TEACHER EDUCATOR: A SELF-STUDY
}

\author{
A. Hiralaal \\ School of Education \\ Durban University of Technology Pietermaritzburg Campus \\ Pietermaritzburg, South Africa \\ e-mail: anitah@dut.ac.za
}

\section{ABSTRACT}

My self-study involved an exploration of my role modelling as a teacher educator of accounting pedagogy. I became aware that there seemed to be a living contradiction in my practice. I suspected my educational values were not being adequately played out in my teaching when students told me they teach as I teach them. Therefore, the purpose in undertaking this research was to align my teaching with my educational values in order to improve my practice by developing as a more productive role model. To improve my practice, I adopted a social constructivist studentcentred approach in my teaching and enacted purposeful pedagogies. I used a self-study methodological approach to generate data. Working with students, colleagues and critical friends and the educative conversations I had, I constructed my living educational theory which reflected the human reality of my work because it was grounded in my embodied values

Keywords: Critical friends, educational values, living contradiction, living educational theory, purposeful pedagogies, role modelling

\section{INTRODUCTION}

Irrespective of the new knowledge that is taught to student teachers in their teacher education programmes, they are often swayed by the principles and actions of their teacher educators. These principles and actions are guided by the educational values that teacher educators subscribe to (Izadinia 2012). Educational values encompass the "ontological, epistemological, social and political" stance that teacher educators adopt (McNiff and Whitehead 2005a, 58). In other words, this is the living standards of judgement that inspire the work of teacher educators. Educational values act as guiding principles in teacher educators' actions by influencing the methods, teaching strategies and teaching activities they select to create meaningful learning experiences for their students. Teacher educators' role model their educational values for their students through their actions as teacher educators (Lunenberg, Korthagen and Swennen 2007). This has an impact on the professional development of the student in their current lives as well as their experiences that are still to come (Izadinia 2012). 
Teacher educators, through their role modelling, should encourage student teachers to take control of their lives and become pioneers of change so that they grow into effective teachers. However, Kosnik (2003) believed that if the teacher educators themselves do not fully engage with their own experiences, it is unlikely that students will benefit from their teacher educators' lessons. Loughran and Berry $(2005,197)$ conceded that when teacher educators model the "thoughts and actions" supporting their ideologies about education, this transforms into "more powerful teaching and learning about teaching". Loughran and Berry further suggested that because teacher educators have first-hand experience of the process of teaching about teaching, it is vital for them to display this understanding to their pre-service teacher education students.

However, in my practice, I suspected that I was not role modelling the thoughts and actions underpinning my practice when students informed me they teach as I teach them. Whilst I subscribed to the educational values of a social constructivist student-centred teaching approach, students informed me that this was not evident in my teaching activities. Whitehead $(1989,41)$ emphasised that if your educational values are not demonstrated in your teaching, it suggests a "living contradiction" that acts as an impetus to study your practice. Therefore, researchers such as Menges (1994) offered that, one sure way for teacher educator to improve their practice is to be mindful that their educational values are acted out in their teaching. Furthermore, Russell (as cited in Loughran and Russell 2013) emphasised that when teacher educators' attention were drawn to this contradiction and they wished to taper it, they were inclined to adopt the research techniques of self-study of teacher education practice.

Hence, my research question was, "How can I improve my practice so that I can develop as a more productive role model?" To answer this research question, I undertook a self-study of my role modelling as a teacher educator to determine what I was enacting for my students. The purpose in exploring my role modelling was to ensure that my ideologies and beliefs about teaching were being acted out in my teaching activities. To develop into a more effective teacher educator, I enacted “purposeful pedagogies” (Samaras 2011, 136) by adopting a student-centred approach to my teaching activities that lent itself to the social constructivist theoretical perspective. Purposeful pedagogies are the methodologies and teaching styles I used that were related to what students desired instead of a general accounting pedagogy curriculum designed by someone who may not have known the needs of my accounting pedagogy students.

I learned that the implicit messages teacher educators send to the students during their teaching actions were more effective than what they teach them (Lunenberg et al. 2007). Lanier and Little (as cited in Lunenberg et al. 2007, 588) agree with this statement when they say "the way teacher educators model the promotion of certain views of learning could be a more important factor in shaping teacher behaviour than the content of the messages they are 
sending". Furthermore, Lunenberg et al. (2007) conceded that teacher educators sometimes are oblivious of what implicit messages they are sending to their students by their actions and behaviours thereby heightening the necessity for teacher educators to explore their role modelling.

Korthagen and Lunenberg (2004) suggested that since the 1980's, a number of studies have been done about teacher educators, but these studies concentrated more on the teacher educators' writing of journal articles and the progress of the approved programme of study instead of their instructional activities in the classroom. They endorsed the fact that the reason for this was that very little was known about teacher educators' instructional activities despite them being accountable for the type of teachers that were produced. In addition, research on accounting pedagogy teacher educators' role modelling has drawn a blank. Consequently, this investigation into the role modelling of a teacher educator will yield much needed knowledge in this under researched area.

Goodman and Fish (1997) advised that discrepancies between teacher education curricula and social constructivist approaches, and the inability of teacher educators to demonstrate this for their students, demoralises student teachers because this makes them feel that their voices are not important in education. On the other hand, Michalec's (1999) research insinuated that when teacher educators intentionally demonstrate social constructivist teaching approaches in their classrooms, their students are provided with a chance to learn about the philosophies of constructivist teaching which they might not have been exposed to otherwise.

I became aware that whilst social constructivism was becoming prevalent in teacher education curricula, a living contradiction was that preservice teachers were not demonstrating the characteristics of social constructivism in their practice teaching (Zeichner and Tabachnick 1981). Zeichner and Tabachnick concluded that the reason for this could be that the teacher educators teaching these students were not enacting the ideologies of social constructivism for these students in the classrooms.

\section{ACCOUNTING PEDAGOGY FROM A SOCIAL CONSTRUCTIVIST PERSPECTIVE}

Accounting pedagogy is the study of how accounting knowledge and skills are exchanged in an educational context and related to the "distinctive nature, structure and epistomology of the subject in a formal situation" (Rossouw 2002, 6). This basically means the methods and techniques that teacher educators use to ensure that learning takes place in accounting education. Marshall, McCrea, and Hillery (2014) define social constructivism as a teaching approach that brings together the varied skills of those within a group to create knowledge. In terms of this approach, the diverse expertise of persons in the same group yields a number of 
different viewpoints and elucidations of the one phenomenon, thereby leading to an enhanced comprehension of the phenomenon. Hence, I designed my accounting pedagogy lessons to involve much group work, peer-assessment and peer-teaching.

Pratton and Hales (2015) discovered during their research, that students in a social constructivist educative setting who participated actively in the lesson performed better in assessments than those who were present in the customary lecture. Pratton and Hales also took note of the fact that the students who took part in discussions and deliberations and engaged in dialogue with others about their beliefs and perspectives eventually arrived at logical deductions on their own. I therefore involved my accounting pedagogy students actively in the classroom by engaging them in debates and discussion sessions for example, students held a debate on the advantages and limitations of the Curriculum and Assessment Policy for Accounting Grades 10-12 as opposed to the National Curriculum Statements for Accounting Grades 10-12.

Hussain and Sultan (2010) encouraged me to be mindful that when I wished to enact my lessons in a social constructivist manner, I would be teaching academic as well as social learning among my students, thus enabling them to live and work in the 21 st century. Similarly, Hussain (2012) found that in a regular teacher centred classroom, the teacher takes the main stage during the activity of learning but in a social constructivist class, students are excited about taking the lead role in their learning. I also learned that understanding of concepts can be socially constructed through students interacting with each other and exchanging ideas and perspectives (Putnam and Borko 2000) which I enacted by providing the accounting pedagogy students with opportunities in class and online to engage in chats and discussions about topics in the curriculum.

I asked students to use the accounting pedagogy topic of Teaching Aids and Teaching Resources and prepare any game, simulation or musical activity to show their understanding of this topic. Amongst other activities, students planned and delivered a show that involved a mock Zulu wedding were the vows and the priest's speech was about teaching aids and teaching resources. They also designed a sketch and developed a rap item with the content from this section. It was hilarious but at the same time a fun and exciting way to learn. I held discussions with my students and engaged in educative dialogue in the class after these activities to discuss the effectiveness of these purposeful pedagogies. Feedback from students assisted me in transforming my curriculum so that I was catering for students' needs. I also involved colleagues whom I invited to my class to watch my debates and my students' shows. I discussed with them after these activities and they provided me with constructive feedback on what they thought were effective strategies and what were not. I also engaged with critical friends who are other self-study scholars whom I meet with in regular monthly self-study cohort meetings. 
I took photographs and videotaped my lessons and presented it to my critical friends. In addition to giving constructive feedback on my work, we engaged in scholarly discourse on my purposeful pedagogies and I elicited constructive feedback which helped me transform my practice.

Hence, I predicted that adopting a social constructivist approach would prepare my students with academic insightfulness, coherent thought, and exploratory abilities (Li 2001). Li commented that students, when having such skills, will be able to link their prior understandings to their new understandings in the learning process and thereby build new knowledge. Dhindsa and Emran (2006) offered that new knowledge is constructed during specific learning, contemplating and engaging with other students and teacher educators and the existing technology.

I was intrigued by Hussain and Mahmood (2010) who recommended that effectual education has a direct relationship with effectual teaching. Hussain (2012) undertook a study on the impact of utilising a social constructivist approach in an educative setting, which revealed that students took much delight in interacting with each other and sharing their expertise with others in the classroom. He elucidated that this provided more opportunities of attaining knowledge while simultaneously helping students to accept diversity in the classroom.

I read that when teaching accounting pedagogy from a social constructivist perspective, I should not be regarded as the knower of all knowledge who has answers to all questions but wishes to learn with others. Instead of being identified as the provider of all the knowledge, I could be labelled as the "collaborator or a coach for students as they gather and evaluate information for themselves" (Jonassen 1991, 5-6). My responsibility should be that of an initiator of learning because the social constructivist teacher educator should not be providing the knowledge but rather initiating the learning process by inspiring students to engage vigourously with the subject content and be able to develop their own questions and interact with their peers to find different answers to their questions.

Rather than sitting quietly and relying on me to provide the answers to their questions, students in a social constructivist accounting pedagogy classroom should be working in a team with other students and research possible answers to their questions and in so doing will enrich their educative experiences. By researching what is required and the ways to achieve it, students will find out what is needed and search for ways to attain it. In this way, students can act as coproviders of the knowledge. They can achieve this by cooperating with each other and work in teams in discovering, ascertaining and generating distinctive results to learning problems. I should then become a "resource model, a helper who encourages exploration and attempts to find unique solutions to problems" (Jonassen 1991, 2-6). 


\section{ROLE MODELLING FROM A SOCIAL CONSTRUCTIVIST PERSPECTIVE}

I learnt from Bahmanbijari et al. (2016) that in every teacher educator's practice there is a mixture of industrious and adversative role modelling. They exhibited to me that critically thinking with student teachers on these practices would provide me, and the student teachers, with valuable lessons on role modelling. Bahmanbijari et al. claimed that without exposure to these practices, students may not acquire the knowledge they need to know. They proposed that being a productive role model was an objective to be sought perpetually because not everyone can lay claim to being an efficacious role model all the time. Henceforth, my desirous objective was to be the best role model that I could be.

I predicted that participating in deliberations, profound visionary thinking, and scholarly dialogue with my contemporaries is likely to develop me into a more dynamic role model (Cruess, Cruess and Steinert 2008). Cruess et al. (2008) added that in spite of the adversities of our everyday duties as teacher educators in conjunction with our organisational accountabilities, if we refrain from interacting with one another in evocative interchange and discourse, it will therefore be an opportunity missed, to learn from each other's experiences. I was rightly reminded by Inui (2004) of the informal curriculum comprising unplanned events that take place during teaching and learning, and which is just as daunting as the formal curriculum if not more. More importantly, I became aware that many of the damaging consequences of negative role modelling takes place in the informal curriculum.

\section{MY LIVING EDUCATIONAL THEORY}

Living educational theory, according to Whitehead (2008, 104), "is an explanation by an individual for their educational influence in their own learning, in the learning of others and in the learning of the social formation in which they live and work". Whitehead explained further that a living educational theory is created when a teacher educator seeks to use innovative strategies in an attempt of enhancing her teaching and learning activities after becoming aware that a disjuncture exists between her educational beliefs and her teaching actions. This disjuncture, labelled a living contradiction transpires when a teacher educator becomes aware that she is refuting instead of acting out her teaching beliefs in her teaching situations. A theory, as explained by Whitehead $(1989,42)$, is merely a "vehicle for explanation and prediction". My simple interpretation of this explanation was that, by gaining an understanding that when constructing my living educational theory, I was actually getting an in-depth knowledge of my self-study research and then making educative decisions guided by the results revealed by my self-study research. 
I understood from Whitehead and McNiff (2006) who were in agreement that I was developing my living educational theory in a specific social milieu. Further comments from Whitehead and McNiff (2006) state that engaging with students and contemporaries and the educative dialogues that you engage in will affect how you develop your living educational theory mainly as a result of the fact that a living educational theory is unlike the normative theory. The variance exists in that living educational theory is representative of the beliefs of the researcher in a particular social context. With reference to my study, the reflective sessions I engaged in with my students about the innovative and creative teaching strategies I was implementing in my teaching developed into my living educational theory. My associates spent some time in my classroom observing me acting out my purposeful pedagogies and the feedback I received from them after my lessons also contributed to my living educational theory My lessons were also video recorded and I watched these videotapes repeatedly and wrote reflections after each viewing in my reflective journal. I presented my reflections in the form of collage portraits which I discussed with my critical friends at the monthly self-study cohort meetings. We engaged in meaningful dialogue where my critical friends constructively critiqued my work whilst providing me with different ideas and perspectives about my classroom practices. Hence, these educative conversations opened my eyes to the living contradictions in my practice which were not that visible to me previously. This helped me to transform and develop new ways of engaging with my students which resulted in my living educational theory. Not only did my practice transform, but I transformed as a person. Whitehead $(1989,42)$ postulated that a theory is merely a "vehicle for explanation and prediction" and based on scientific tried and tested methods but a living educational theory is developed by a researcher personally when she identifies a living contradiction in her practice and then envisions new ways of improving her practice. Hence, I constructed my living educational theory which reflected the human reality of my work because it was grounded in my embodied values because my transformed practice embodied my educational values of a student-centred social constructivist approach.

Whitehead (1989) provides a comprehensive account of developing a living educational theory. He suggested that the researcher will initially collect information on her teaching actions which she can do by videotaping her lessons so she can see where her teaching beliefs were not being enacted in her actual teaching. Whilst conducting this research, she can also explore some possible answers to the enquiries she has on how she can prevent herself from refuting her educative values in her actual teaching.

The researcher then implements the ideas that she has researched in an attempt to enhance the delivery of her subject. Thereafter, she will evaluate the impact of the new ways she has 
found to implement in her practice. I am led to believe that because the researcher in assessing her new teaching strategies also documents how she has developed as a professional relative to the changes in her educative practice, the exploration lends itself to the research methodology of self-study. This reminds me of what Mitchell and Weber $(1999,231)$ said about this change that takes place which they termed "re-invention". Mitchell and Weber claimed that "when you reinvent yourself not only do you bring about changes in your pedagogical practice, but you reenvision yourself".

\section{METHODOLOGY}

My literature search on self-study research methodology highlighted that teacher educators like myself who wanted to explore their practice with the intention of enhancing and enriching their practice could embark on self-study of teacher education practice (Pinnegar, Hamilton and Fitzgerald 2010). Beck, Freese, and Kosnik (as cited in Lassonde, Galman and Kosnik 2009, 10) described self-study as "an inquiry-oriented approach that is personal, reflective, collaborative and constructivist". This led me to believe that self-study was inquiry-oriented because while undertaking my research I will be enquiring how I can enhance and enrich my practice.

Being a self-study, it is understandable that I was the main respondent in this study. Additionally, I elicited data with my 92 second year students and 56 third year students. These students were registered for a four-year Bachelor of Education degree with economic and management sciences subjects as their major areas of study. A large number of these students were the first in their families to attend university while a small number of students had parents who were professionals with academic qualifications.

I divided my data gathering procedure into different times. Prior to my changing my teaching approaches, I collected data from my students. Then I put my innovative and creative teaching approaches into action and generated data with my students. Together with my students, I elicited the evidence that was required for my study by videotaping my teaching activities. The point in recording my lessons was for me together with my colleagues and critical friends to pinpoint sections of my teaching where I was negating my educational beliefs.

I was educated by Whitehead (1989) who stated that when repeatedly viewing the videotapes of your teaching activities, you become aware of the teaching sessions where you are negating your teaching values. When you become aware of this contradiction, then only are you able to work towards refining and revitalising your practice. Whitehead (1989, 41-52) based this assumption on the idea that you "reconstruct your educational theory" because the videotaped lessons provides you with the opportunity to view your teaching with your 
contemporaries who will aide you in pointing out your areas of weakness.

When my areas of weakness become explicit to me, it created an avenue for me to work on addressing these areas of weakness by ensuring that my teaching beliefs were evident in my teaching actions. I had created a mental picture that I was the perfect accounting pedagogy teacher educator. However, the camera told me a different story. I assumed I was the picture of perfect role modelling but what I assumed and what the camera revealed was a total contradiction. The camera revealed the truth that I was negating my educational values.

Besette and Paris (2016) highlighted for me how I could motivate students to cultivate their own teaching philosophies. They recommended that I involve students in an activity of selecting a metaphor that depicted them as future teachers in the classroom. However, I went a step further and got students to select and draw a metaphor of me as their teacher. This was another data generation strategy that I employed.

Additionally, I created a reflective questionnaire that asked students to reflect on the most constructive as well as the most ineffective lessons they had experienced in accounting pedagogy lectures. I distributed the questionnaire to all my second and third year accounting pedagogy students but not all students responded to the questionnaire. Nevertheless, I gathered evidence from those students who had completed the questionnaire and used the information as data for my study.

The institution where I am employed conducts online evaluations annually called Lecturer Evaluation Questionnaires (LEQ). Students complete these surveys anonymously which gives the students an opportunity to freely express their opinions without fear of recrimination. These institutional questionnaires asked a variety of questions about my ability to speak audibly and unambiguously, my skills of asking appropriate questions and the techniques I used for engaging students in discussion, how I involved students in the learning process and how timely was the feedback I provided to students on assessments and my ability to respond favourably to students as well as my approachability. In conclusion, I utilised the assessment form that lecturers use to evaluate students during their teaching practice sessions and asked students to assess my lectures. This lesson assessment form evaluated my classroom and lesson management ability, my pedagogical knowledge as well as the subject content knowledge and my ability in understanding my students. It also assessed my capability in choosing and designing, planning and implementing comprehensible teaching goals and aims.

\section{DISCUSSION}

The information I gathered before I enacted my new approach to teaching revealed that I was not the ideal accounting pedagogy teacher educator that I envisioned I was. When students had 
described me as a Ferrari, I was very pleased with myself especially when I read this: "We see Mrs. Hiralaal as this Ferrari because she is very powerful in her teaching".

It was only after I read further about why they compared me to a Ferrari, that I became worried. The students explained that immediately you start up the engine in a Ferrari, you can see that this car has power and speed. But just as a Ferrari takes off at top speed and can maintain the speed, I too commence my lessons with speed and keep the momentum going throughout the lesson. I wait for no one and listen to no one. I never stop for a minute to enquire whether what I teach has been understood and in the same vein, I do not ask questions. In fact, on the rare occasion when I do ask a question, I do not have the tolerance to wait for students to answer but I provide the answers to my own questions.

Maintaining this theme of power and speed, students also depicted me as an aeroplane. They explained that an aeroplane has to fly according to a specific schedule and speed and cannot afford to squander time. Likewise, I speed through the lesson and move from one topic to the next similar to an aeroplane that flies to and from different places. Furthermore, an aeroplane never flies with other planes close by but flies alone in the sky. When I teach, it seems that I have no connection with students because I am like an aeroplane flying alone in the sky. Neither do aeroplanes discriminate against any passenger but all passengers are treated equally. So too, I teach all students the same and there is no curriculum differentiation because maybe I was assuming that all students will learn in a similar manner and at the same speed. Students informed me that after my lesson, they have to have some quiet time where they try and assimilate what had just been taught in my lesson.

After reading these explanations, I became extremely despondent. I did not realise that my students whom I thought were learning from me, were actually victims at my hand having to go through my desire of wanting to get as much information syphoned into them at all costs. Sadly, I continued reading their explanations and I was relieved that students had described me next as the sun. I thought for a moment, all was not doom and gloom because they said I was comforting like the warm sun on their faces. They also said I was a happy person with a friendly and motherly disposition and just as the sun helps young plants to grow and bloom and brighten the surroundings, I was this person that exuded warmth and cheerfulness. However, the sun was very far in the sky and no one has ever been able to get close to the sun. In a similar manner, whilst I touched each of them with my mannerisms, I could not do the same with my teaching. I isolated them when I was teaching because I lost them somewhere in between.

Similarly, students likened me to a jacaranda tree because like the jacaranda tree with its enduring thick roots that withstand any adversity, I had strong solid subject content knowledge. I was thrilled when they described me as a "warrior teacher" and claimed that I instilled such 
strength into them concerning the subject content that no one could fault them in this. But then a warrior wants to be in control and will fight to the bitter end to maintain this power over others. Maybe, I was seen as a warrior teacher because I would fight to take charge of every event in the class leaving no room for flexibility. I was rigid in the way I taught.

I was also comforted when I read that some students had called me a lamplighter and stated I lead the way. However, when I reflected on this depiction of me, I questioned myself. It was well and good that students thought I illuminated their minds just as a lamplighter illuminates the surroundings. I asked myself exactly what did I illuminate their minds with? I came to see that I illuminated their minds with pure accounting pedagogy content. But was I training them to illuminate the minds of their future learners so the learners will irradiate that spirit and glow which will brighten their pathways as lifelong learners. My reflective exercise caused me to doubt this because it came to light that I had not given them the chance of being in control of their own learning, so they could stumble, but get up and learn from their stumbling. I was not illuminating their paths to become independent perpetual learners but gearing them to regurgitate the facts I had drilled into them which they were bound to forget after writing the examinations.

Dewey $(1934,120)$ wrote, "there is a temptation to assume that presenting subject matter in its perfected form provides the royal road to learning". By the same token, I strongly thought that being a good teacher educator meant cramming their heads full with facts. However, my exploration into my role modelling conscientised me to accept the truth. My students were victims of knowledge overload. My self-study research helped me to see that this was counterproductive to their learning.

My self-study has thus inspired me to try to give students an avenue to explore, make mistakes and learn from their own mistakes. It was not in their best interest for me to shield them from falling, hurting themselves but learning from this mishap. I should release them from the cocoon I had entrapped them in by exposing them to purposeful pedagogies in my social constructivist student-centred classroom.

\section{ENACTING PURPOSEFUL PEDAGOGIES}

The disjuncture I identified between my educational beliefs and my teaching activities catalysed me into pursuing a social constructivist approach to my teaching using "purposeful pedagogies" (Samaras 2011, 136). Samaras $(2011,137)$ explained that "purposeful pedagogies" which you may be willing to put into your practice arise from what she terms "noticing". Likewise, when I "noticed" that the teaching methods I was using was not yielding the result I desired with my students, I sought to implement more effective strategies like role playing and oral storytelling 
sessions all related to accounting pedagogy. Rather than aiming to be the master of all knowledge, I strove to collaborate with students and assist them to develop not the aims for teaching but rather the aims and objectives for learning.

I attempted to create a learning climate where students were provided with the opportunity to select what they wanted to learn and how they wanted to learn this. In this way, I was attempting to promote students who could take responsibility for their own learning by making the right choices and strive towards becoming independent thinkers who can not only reason logically but be mindful that they will have to live with their choices. I wanted to develop passionate students who would become passionate teachers, secure in themselves but brave enough to transcend the boundaries of what is regarded as regular. I did not want to create rebels. On the contrary, I wanted students to have the fighting spirit of rebels in the classroom and exude confidence and maturity coupled with an adventurous streak so they can experiment in the classroom.

Students were once again asked to repeat the exercise of finding a metaphor that best depicted a transformed me and draw this metaphor. Unlike the metaphor of the Ferrari previously, students chose a gardener to depict the changed me. They gave me a gentle calm persona drawn in pastel shades looking rather at ease in the garden. By drawing me as this gardener, they illuminated my transformed self because like the gardener, I was unsure whether the seeds I was sowing will germinate and flourish in abundance or just shrivel up and perish. They likened this to my adopting the new social constructivist approach to my teaching whereby I was placing them at the centre of the learning process. Like the gardener, the outcome cannot be predicted but the gardener hopes for the best results by watering and tendering to the seeds regularly.

Accompanying the representation of me as gardener, students depicted me as a baker. Just as baker selects and combines various components and mixes them altogether to produce a delightful end result, I was picking superior quality teaching strategies and mixing these with the finest materials which is my subject content, and using the most effective utensils which is my teaching resources and teaching aids in order to get the desired results.

Lastly, students represented me as a butterfly in their metaphor drawings. On probing them about why they thought I had transformed into this delicate creature, they clarified that they could see the visible change in me. They felt, not only had I become more relaxed as a teacher, but my demeanour had undergone a drastic change which manifested in the transformed approach I was adopting in my teaching. They likened me to this butterfly that morphasised like the caterpillar does into a butterfly. I was very cautious in my teaching previously and wanted to do everything by the book. Very rarely did I take stray from the norm 
but like a butterfly that escaped the cocoon, I was spreading my wings in my teaching and breaking boundaries.

Inclusive teaching became my priority as I realised that my students were not all going to learn the same way at the same time. I elicited feedback from students after each lesson where I asked questions on their understanding and comprehension of the lesson content that was taught. I questioned students on what they had problems with and what we, that is the students and myself, could do to resolve these misunderstandings. I used the feedback that I had prompted from students to plan the forthcoming lessons and this provided an opportunity for the students to have a voice in their learning.

I no longer tested mere recall of facts and preparing students just to write the examinations. I now developed assessments that required students to think critically and creatively and apply what they had learned to different scenarios. By doing this, I was no longer centred on marks and concerned only with what students had learned. Instead, I gave more attention to how students learned and what they could do with what they learned. In so doing, my intention shifted to moulding and shaping my students to became globally portable future citizens whose learning was an ongoing process.

I adopted a different strategy with my teaching where I was not the main focus of attention and standing in the front. In its place, I got students to sit in groups and interact with each other and exchange ideas. I encouraged students to engage with each other in online discussion chats. I was no longer the expert knowledge provider where I wanted to be in control and set out every step of every lesson and steer the procedure of how the lesson progressed. Rather, I let the lesson flow according to the response I got from students when I posed an initial guiding question to the class and then I let the lesson proceed from there. I did this to motivate students to actively engage in the lesson as I did during the oral storytelling activity. During this activity, I persuaded students to relate their own stories that involved money and in this way, students learnt from their own lived experiences.

Enacting purposeful pedagogies from a social constructivist perspective contributed to the improvement of my practice. I became aware of this from the metaphor activity and also messages that students sent to me via e-mail for example:

\section{"Dear Mrs. Hiralaal}

I also wanted to tell you that I have really enjoyed your teaching. I have learned the most from your lectures compared to my other specialisations. Thank you for your passion for teaching, I have felt the difference.

TZ" 


\section{CONCLUSION}

The stimulus for embarking on this self-study was for me to bring into line my instructional practice with my teaching beliefs in order to attend to a living contradiction I identified in my practice so that I could advance towards becoming as a more productive role model for my students. Despite the fact that I did come to enact purposeful pedagogies, the way forward is for me to continue to re-envision myself. I have come to realise, through my self-study research practice, that although I have begun a process of reinvention, this is not going to be a rushed process that can be effected within a few months. Nor is the growth going to end at some point. As my educational values evolve in response to, and in relationship with, my lived experience and significant people in my life, I will be changing and learning.

Samaras et al. (2014) suggested that self-study forces you to confront your inadequacies and in so doing, you become more mindful of incongruities in your practice. As Samaras et al. $(2014,368)$ commented, self-study is not linear and orderly but is characterised by "messiness, uncertainty and complexity" and for me this is what makes self-study so appealing.

\section{REFERENCES}

Bahmanbijari, B., A. Beigzadeh, A. Etminan, A. R. Najarkoloi, M. Khodaei, S. M. S. Askari. 2016. The perspective of medical students regarding the roles and characteristics of a clinical role model. Electronic Physician 9(4):4124-4130. doi: 10.19082/4124.

Besette, H. and N. A. Paris. 2016. Drawing on metaphors of teaching to elicit reflexive thinking. Kennesaw State University Faculty Publication (3895).

Cruess, S. R., R. L. Cruess, and Y. Steinert. 2008. Role modelling - making the most of a powerful teaching strategy. BMJ 336(7646): 718-721. doi:10.1136/bmj.39503.757847.BE (Accessed 16 July 2016).

Dewey, J. 1934. Art as experience. New York: Balch.

Dhindsa, H. S., and S. H. Emran. 2006. Use of the interactive whiteboard in constructivist teaching for higher student achievement. Creative Education 3(2): 175-188.

Goodman, J. and D. R. Fish. 1997. Against-the-grain teacher education: A study of coursework, Field Experience, and Perspectives. Journal of Teacher Education 48(2): 96-107.

Hussain, I. 2012. Use of constructivist approach in higher education: An instructors' observation. Creative Education 3(2): 179-184.

Hussain, I. and S. T. Mahmood. 2010. Practice teaching or internship: Professional development of prospective teachers through their pre-service training programmes. Journal of Educational Research 13: 105-122.

Hussain, I. and S. Sultan. 2010. Learning by doing: Outcomes of teaching a research course through group activities. Global Science and Technology Forum, Singapore City.

Inui, T. S. 2004. A flag in the wind: Educating for professionalism in medicine. On Being a Doctor 154: 63-64.

Izadinia, M. 2012. Teacher educators as role models: A qualitative examination of student teachers' and teacher educators' view towards their roles. The Qualitative Report 17(24): 1-15.

Jonassen, D. H. 1991. Objectivism vs constructivism. Do we need a new philosophical paradigm? 
Educational Technology Research and Development 39(3): 5-14.

Korthagen, F. A. J. and M. Lunenberg. 2004. Links between self-study and teacher education reform. In International handbook of self-study of teaching and teacher education practices, ed. J. Loughran, M. L. Hamilton, V. K. LaBoskey and T. Russell, 421-449. Dordrecht/Boston: MA: Kluwer.

Kosnik, C. 2003. Reflection in teacher education: It starts with me. Online Journal for Teacher Research $6(1)$.

Lasonde, C., S. Galman and C. Kosnik. 2009. Self-study research methodologies for teacher educators. Rotterdam. Netherlands: Sense Publishers.

Li, W. 2001. Constructivist learning systems: A new paradigm. International Conference on Advanced Learning Techniques, Madison.

Loughran, J. and A. Berry. 2005. Modelling by teacher educators. Teacher and Teacher Education 21: 193-203.

Loughran, J. and T. Russell. 2013. Teacher educators as members of an evolving profession. In International handbook of teacher education, ed. M. Kleman Ben-Peretz, S. Reichenberg, R. Shimoni and S. Lanham. New York, Toronto, Plymouth, UK: Rowman and Littlefield Publishers Inc.

Lunenberg, M., F. Korthagen and A. Swennen. 2007. The teacher educator as a role model. Teacher and Teacher Education 23: 586-601.

Marshall, S., J. McCrea and M. Hillery. 2014. Talk. social constructivism. http://epltt.coe.uga.edu/index.php?title=Talk:Social_Constructivism.

Menges, R. J. 1994. A study of newly hired post-secondary school faculty. In Teacher thinking, beliefs and knowledge in higher education, ed. M. Weimer, 81-81. Pennsylvania: Pennsylvania State University National Centre

Michalec, B. 1999. Clinical experiences during preclinical training: the function of modeled behavior and the evidence of professionalism principles. International Journal of Medical Education 3: 37 45. doi: 10.5116/ijme.4f42.5c99.

Mitchell, C. and S. Weber. 1999. Reinventing ourselves as teachers: Beyond nostalgia. London: Falmer Press.

McNiff, J. and J. Whitehead. 2005a. Action research for teachers: A practical guide. London: David Fulton Publishers,

Pinnegar, S., M. L. Hamilton and L. Fitzgerald. 2010. Proceedings of the eighth international conference on self-studies of teacher education practices: Navigating the public and the private: Negotiating the diverse landscapes of teacher education. Self-Study of Teacher Education Practices SIG., Herstmonceaux Castle UK.

Pratton, J. and L. W. Hales. 2015. The effects of active participation on student learning. The Journal of Educational Research 79(4): 210-215.

Putnam, R. T. and H. Borko. 2000. What do new views of knowledge and thinking have to say about research on teacher learning? Educational Researcher 29(1): 4-15.

Rossouw, J. D. 2002. Learning area didactics. Teaching economic and management sciences. Pretoria: Unisa

Samaras, A. P. 2011. Self-study teacher research: Improving your practice through collaborative inquiry. London: Sage.

Samaras et al., 2014. The shark in the vitrine: Experiencing our practice from the inside out with transdisciplinary lenses. Journal of Transformative Education 12(4): 368-388. https://doi.org/ $10.1177 / 1541344614551637$

Whitehead, J. 1989. Creating a living educational theory from questions of the kind, "How do I improve 
my Practice?" Cambridge Journal of Education 19(1): 41-52.

Whitehead, J. 2008. Using a living theory methodology in improving practice and generating educational knowledge in living theory. Educational Journal of Living Theories 1(1): 103-126.

Whitehead, J. and J. McNiff. 2006. Action research: Living theory. London: Sage.

Zeichner, K. M. and B. R. Tabachnick. 1981. Are the effects of university teacher education "washed out" by school experience? Journal of Teacher Education 32: 7-11. 